\title{
Delineation of the Path Dependence in Development of Central Business Districts (CBD) in Turkey's Kayseri
}

\author{
Neşe Yılmaz Bakır ${ }^{*}$ \\ ${ }^{1}$ Department of City and Regional Planning, Faculty of Architecture, Erciyes University, 38039 Kayseri, Ahmet El Biruni Street 104, \\ Turkey \\ * Corresponding author, e-mail: nyilmaz@erciyes.edu.tr
}

Received: 06 January 2020, Accepted: 27 February 2020, Published online: 27 May 2020

\begin{abstract}
This article examines the demolition-oriented restructuring relationship during urban development processes in the case study of the central business district in Kayseri (Turkey) by systematically analysing externally-conditioned events and trajectories. This transformation, characterised by changing periods of development and the analysis of the actors who are particularly active in the process, is explored through the socio-spatial developments in Kayseri. In this study, this has been expounded through the concept of path dependence, which states that current conditions are more dependent on past events and those past events lead to today's results. The decisions on the historically contingent periods and three critical junctures identified in the study were found to have been maintained until the next stage and strengthened by following the path-dependent tendency.
\end{abstract}

\section{Keywords}

central business district development, demolition paradox, path dependence, creative destruction

\section{Introduction}

The city centre bears the characteristics of the city, the transformations it has gone through, and traces of its history. Therefore, to get to know and understand a city, examining its centre is an important step. In many AngloSaxon cities, the Central Business District (CBD) is identified as the city centre, but the concept "city centre" differs from the CBD. (Murphy et al., 1955; Murphy, 2017). The concept of the "CBD" revolves solely around economic and financial power, but the "city centre" also includes historical, political, and cultural factors. City centres were the central trade areas where traditional transactions took place on the intersection of transportation networks (Gottman, 1976). Small-scale production and trade were concentrated in city centres before industrialisation, and during periods when urbanisation was slow. In industrial societies, these areas are referred to as the brain of the city because the decision-making, supervision and coordination functions are concentrated here. In this respect, the city centre concept has to comply with the models such as the commercial centre of the city, the business centre of the city, and the cultural centre of the city (Hollenstein and Purves, 2010; Thurstain-Goodwin and Unwin, 2000).
The term Central Business District was firstly proposed by the Chicago School; they consider that a city expands from inner to outer in concentric circles (Park and Burgess, 1925). The spatial structure can be divided into five circles. The centre of the circular structure is the city's geographic and functional core which is the CBD. The CBD of modern society integrates a great deal of financial, business, culture and service institutions, and the supporting facilities, such as office buildings, hotels and apartments with convenient traffic, communications and other infrastructure, a favourable economic development environment and places that are convenient for commercial activities. In addition, corporate headquarters, financial centres and specialised production service are three functional structures of the present $\mathrm{CBD}$. These regions typically integrate many facilities, such as financial, business, cultural, service facilities and commercial offices, hotels and apartments and other amenities. These also possess a modern infrastructure and a favourable environment, such as convenient traffic and communications (Carter, 1982; Chapin and Hightower, 1965; Yaguang, 2011). 
When examining the concept of CBD, it is not entirely satisfactory to analyse the urban socio-spatial structure of Turkish cities with models based on the Anglo-Saxon city. In Turkey, unlike the Anglo-Saxon city, CBD and city centre concepts have different spatial features, and these two different areas of the city decompose in an urban texture. The areas of these two different characters are located in the same space, especially when CBD projects put pressure on development in the city centres containing the historical texture. Arû (1998) claims that traditional Anatolian cities were organic, free, and rhythmic, not geometric. According to Cezar's studies on Turkish cities, the sites of the bazaar (the commercial centre) were placed near the fortification walls of the cities. Therefore, the bazaars were the cores of the cities and cities expanded around them. The propinquity of the bazaar to the fortification walls is a feature that existed in both walled and unwalled cities. If there is no inner fortress in a walled city, or if the fortress is built in the corner of the city walls, the bazaar develops at a site most suitable for the movement of people (Cezar, 1983).

Over time, the rapid and continuous change observed in transportation, communication, means and techniques of production has led to functional, social and spatial changes in central business districts. While the city was purely a physical production area originally, it increasingly became a place where labour was reproduced and eventually the focus for capital accumulation with the industrial revolution (Haughton and Hunter, 2004). While the transition to the modern world with urban industrial structuring meant "intervention to the existing structure and transforming it" in the process of urban restructuring, the most remarkable implementation in this process has been "the destruction of the old, the replacement of it by the new" (Thorns, 2002:p.46). In this process, most of the city centres were demolished and instead, city centres representing "modern" urban structure and central business districts appropriate to the zoning approach were created.

Today, economic restructuring has changed the spatial distribution of distributive, social, productive and personal services (Stein, 2003). In this process, capitalism has succeeded in creating a perception of the city as a commodity to be bought and sold through new ideological and economic neoliberal policies, which are its last stages. Thus, with the intense consumption norms, cities started to be moved back to the centre of the economy (Sassen, 1991; 2000). Increasing changes in the means of production and the concentration of the service industry in cities brought about change in the production and employment structure. Sectors such as finance, banking, marketing, and advertising started to be concentrated in this location and again resulted in changes to the local organisation of central business districts (Bryson and Daniels, 2007; Bryson et al., 2004). Cities are being structured and continuously reorganised within the context of the fundamental socio-local forms, ranging from buildings and built-up areas to aspects of land use, productive and logistical networks, and infrastructure organisations on a metropolitan scale to increase the profit accumulation capacity of the capital holders (Şengül, 2009; Theodor et al., 2012).

This city centre oriented pressure for change is following a similar path in Turkey. Along with big cities like Istanbul, Anatolian cities are also experiencing this process at different speeds, manners and relationship networks; they are trying to manage this development in various urban trajectories with both foreseen and unforeseen results (Lovering and Türkmen, 2011; Ozus et al., 2011).

The city of Kayseri, the site of the study, emerges as a city differentiated by its dynamics in this process. It has been developed in a planned manner since the foundation of the Republic, and has undergone a process of locally intense demolition-oriented restructuring and transformation; the aim being to create a "modern" and "civilised" society that would make the secular image of the nationstate popular. This approach also influenced the formation of CBD in the cities of Konya, Gaziantep, and Mersin, as well as Ankara (Keskinok, 2010).

After 1980, with the phenomenon of globalisation in the organisation of production in the city, the pre-modern/ traditional economic and social relations and ties hidden in the locality strengthened, and a period that witnessed the "revival" of the traditional and the cultural started to be experienced (Doğan, 2007a). This process found its spatial equivalent through the emergence of a new demolition-oriented process in which modern traces were erased.

Imagining itself as a global city of the future with numerous visions such as a city of the world, a touristic city, an industrial city that it embraced, production of new profit-oriented projects, new CBDs intended to be implemented by "decentralisation" of the city centre and its reproduction after demolishing the old one emerge as the reflections of the neoliberal policies of the new era after 2000. This process is expressed by path dependence process and the process of lock-in within the scope of the study.

By scrutinising this process affecting the city of Kayseri, implementation of a new interpretation on phenomena not much delved into might prove to be a new opportunity 
for Turkey, and Anatolian cities in particular. The city has developed a dependency model for itself that is continually reproduced after demolition through plans constructed by taking the decisions of the political power as the basis.

This study will address this destructive transformation in terms of planning processes and institutions. The history examined in this study shows that there is a strong political reason for the local government to change policies sharply at critical junctures and that tendencies oriented towards path dependence are reinforced despite the change in the regime after such policies. In this study, the policy change at the level of local governments has been analysed because the growth and transformation management of the central business district of Kayseri is controlled by the local government. Within the scope of the study, the paradox of demolition on the theoretical level will be discussed in the first stage, then the path dependence determined as the method and a literature search on its use in urban works, in particular, will be carried out. In the last section, demolition-oriented regeneration and its motivations in the city of Kayseri, the site of the study, will be described in sequence.

\section{The paradox of regeneration by demolition}

The new has to destroy the old in order to establish, consolidate and maintain its power. This rule applies to almost every field from religion to arts, from politics to science. The use of demolition as a city planning tool is defined through the concept of "building by demolition". The focus of the study is on making the counterparts of construction-demolition processes, both at local and ideological levels, comprehensible.

In the literature search, it became apparent that the reorganisation of urban spaces, removal of the more unfortunate aspects, reshaping cities after they had been transformed into chaotic environments due to intense migration from rural to urban areas during the Industrial Revolution, had a fundamental importance in the second half of the $19^{\text {th }}$ century and the first half of the $20^{\text {th }}$ century. This era was regarded as "a period in which houses and cities could blatantly be thought of as machines to live in" (Harvey, 1999:p.101). This understanding was "inspired by the hope that the idea of restructuring cities all over again would solve not only the urban crisis but also the social crises".

The concept of modern planning seeks an ideal order in the organisation of urban space. The act of demolition manifests itself in the urbanisation stories of many cities such as Paris, St. Petersburg, New York, as a means of modernisation. With the action of demolition, the city is being formed regardless of the history erased through the creation of space for the new. Demolition of Haussmann in Paris, Moses in New York and demolitions in cities in Turkey, coincide with each other. The relationship and experiences that cities around the world create through demolition for the sake of being able to belong to the modern world are similar to each other. To be modern, many experiences are abandoned, and cities are demolished and built again to construct what is new. The logic behind the perception of modernity as a revolution and construction of everything anew (tabula rasa) is the ideal of implementing the life regarded as the ideal for everybody without any discrimination. In its broadest sense, modernism has replaced the features of the context with the concept of tabula rasa. Panayatis Tournikiotis, in his book, The Historiography of Modern Architecture, specified that modern architecture foresaw the systemic elimination of any element that can render the continuation of the classical tradition by Tabula Rasa (Tournikiotis, 1999).

For this reason, Haussmannisation, which has become synonymous with the demolitions in Paris, is an attempt to put a new image "in place of a city that has lost its old ways of representation". Corbusier proposes the complete demolition of the old city, which was not built based on rationalism, and the building of an entirely rational city instead of it. He recommends taking down the irrational, old city plan founded on traditions, beliefs, habits and the roads, streets, buildings, monuments, cemeteries, everything that gives life to this plan (Corbusier, 2014). Berman draws attention to the constructive power of the demolitionist act, the power within it, and states how effective the destructive power of the government is in shaping the city, and that simultaneously bearing the positive and negative aspects offered by the destructive character of modernism makes an individual genuinely modern (Berman, 1982).

Modernity is a rebellion against the normalising functions of tradition and rejects and resists everything that is normative. In this respect, modernism is a society; in a more technical sense, a corporation that lives in the future rather than living in the past, unlike the previous cultures (Giddens and Pierson, 1998). According to Lefebvre, "the Cult (worship) of the transient" is the essence of modernity (Lefebvre, 2000:p.86).

At this point, the concept of "creative destruction", which has a fundamental importance in terms of understanding modernity, comes to the fore. Creative destruction derives from the contradictions that exist within 
modernity and enables the idea of progress, the underlying philosophy of modernism, and a break from history and tradition. In his work "Urban Revolution", Henri Lefebvre placed urbanisation in a special place in the constant reproduction of capitalism by itself (and therefore in the process of producing and consuming the "new"). According to him, "the engine of the capitalist capital accumulation and the driving force of historical change are cities, not industry anymore". This is the clearest and boldest expression that urbanisation is regarded not as a "result (output) of capitalist relations", on the contrary, as a "tool serving for coping with the internal conflicts in it" (Lefebvre, 2003:p.155).

The thesis that urbanisation is a force that creates conditions for capitalism must be handled together with the concept of "creative destruction" that Schumpeter uses by implementing a derivation from Marxist theory. According to Schumpeter, "the development of creative destruction" is the foundation of capitalism, and every capitalist attempt reproduces this process of destruction (Cunningham, 2010:p.21). The "creative destruction" ensuring the continuity of the capitalist system will also produce the new, and thus, destruction and construction will become an inseparable duo. The processes of construction-destruction will enter into a cyclical continuity rather than constructing a relationship of contrast with each other that will automatically destroy the dichotomic attitude.

Demolition is the precondition of the new and also its final product. In this respect, it becomes an indispensable element of the capitalist system because new notions, new products or commodities are only possible with the destruction of the previous ones. The industrial process regularly destroys the old one and creates a new, leading to fundamental changes inside the economic structure. As a factor enabling the continuity of the construction-destruction cycle, David Harvey adapted the concept of "creative destruction" to the transformation process of cities, but with a different view from Schumpeter. Harvey states that the "Creative Destruction" necessitated by the demolitions and deconstructions had its precedents in the revolutionary spirit (Harvey, 2006). The opening of new markets ensures that the capitalist system is continuously innovative and creates new things by replacing the old. For this reason, the foundation of the capitalist system is creative destruction, and urban reconstruction aims to re-plan the new areas created through the demolition of the existing structures in the way that they will attain the economic and social values they have lost.
The creative destruction of space makes it possible to write new zoning codes on it as a kind of infinite tabula rasa. The establishment of "structured coherence" by central and local governments through public administration, planning and cultural policies provides the capital with the opportunity to write out new codes instead of the obsolete ones and to turn space into profitable investment areas. Especially at every stage in which the "capital surplus", which seeks profitable investment opportunities, becomes periodically idle; the space is reproduced again and again. The outdated codes of profitability in a space always leave destruction and devaluation behind after the flight of capital (Harvey, 2000; Jessop, 2018).

It is stated by many researchers that the effects of the neoliberal process strengthened by capitalism are intensely visible in urban spaces (Brenner, 2000; Brenner and Theodore, 2002; He and Wu, 2009; Şengül, 2009). The tools of neoliberalism as the economic background of the global system are implemented in different political contexts at different times and naturally correspond to different meanings and consequences in different institutional situations. What neoliberal agendas, strategies and policies have in common is that they create conflict and contradictions between the principles and practices of urban development planning (Tasan-Kok and Baeten, 2011).

In this system, the social state, institutions and relationships are restructured to fulfil the requirements of the irregular movements of capital. The role of the government is the organiser and facilitator of the creative destruction process. In this context, the understanding of city administration has taken a form that is administrative (managerial), and the local governments (municipalities) have become "entrepreneurs" (Brenner and Theodore, 2002). The social state, which has been relieved of responsibilities and "expectation of reliability" becomes the "guard of the hunting area" (Urry, 2000:p.189). The rollback dimension of neoliberalism, which is simply more than the sweeping off phase, is an integral part of its origins, dynamics and logic (Theodore et al., 2012). In this period, the effective concept and the creative destruction dynamics that have developed never actualise on tabula rasa, where the previous order is "suddenly destroyed, and the new order" is revealed as a fully matured whole. Instead, this dynamic progresses in conflicted areas where newly thriving "designed spaces" interact with regulatory structures inherited in a continuous and conflicting manner, resulting in new, unprecedented and often unstable layers of political-economic space (Lipietz, 1994). 
The main objective of neoliberal urban policy experiments is to activate urban space both as the stage of market-based economic growth and as the platform of elite consumption practices (Brenner and Theodore, 2002; $\mathrm{He}$ and $\mathrm{Wu}, 2009)$. It must be ensured that, as a precondition, the place where the capital will be "temporarily" settled, must allow escape at any time and be transferable to a more profitable place (Urry, 2000). Neil Brenner and Nik Theodore (2005) state that the "project" is replacing the "plan" and that, in this way, the "demolition-oriented restructuring" re-emerges to form the new spirit of urban mobility. In this sense, the current urban process is defined as "the creative destruction of political-economic space on multiple geographical scales"; it is stated that "cities have become significant strategic geographic scenes where a wide range of neoliberal initiatives, with intermingled strategies of crisis recovery and crisis management, are combined together". The new neoliberal system is institutionalised through large "demolition-oriented transformation projects" in urban areas where commodification is incomplete (Brenner and Theodore, 2005:p.102-103).

\section{Research method}

The method used in this study is Path Dependence. The theory of path dependence was developed in the 1980s and was first analysed by economists Paul David and Brian Arthur (Arthur, 1989; David, 1985). Path dependence is a concept that has been studied in a wide range of fields from economy to politics, sociology, strategic management and technology, and about which theoretical and case-oriented studies have been conducted (Table 1).

David summarises path dependence with the phrase "the past is important", and Arthur defines it as "remaining preoccupied and stuck in/on historical events" (Arthur, 1989; David, 1985). The path dependence theory focuses on the structures that restrict the organisation, not on how decision-makers shape the way the organisation develops. Temporal turning points, called critical junctures, emphasise the transition from the path dependence to new path production (Morrison and Croucher, 2010). Critical junctures represent the choice between two or more alternatives and are characterised by a kind of circumstantiality in which an unforeseen event is influential (Booth, 2011; Mahoney, 2000).

Path dependence reveals that the events taking place today are not only the conditions of the day but transpire as a result of many decisions made in the past. According to the path dependence theorists, in a situation where there is equilibrium, the steps taken in the early stages determine which equilibrium will be fixed. These steps have a self-reinforcing effect on the subsequent steps; the most reinforced balance, rather than the most productive one, is that ultimately reached. According to Crouch and Farrel (2004), the equilibrium that is reached is called a "lock-in". Sydow et al. (2009) define the state of lock-in, as the organisation always having to choose the same options and lacking the opportunity to move to different options (Fig. 1). From this point on, decision-makers know that the current situation is not optimal and that more efficient results could be obtained if different options had been preferred in the early stages, but still the current equilibrium cannot be stepped out of (Crouch and Farrel, 2004; Sydow et al., 2009). With the effect of past selections and decisions, an event occurring at a previous point in time affects the possible consequences of events that may occur at a later point (Mahoney, 2000; Pierson, 2000). In the case of increasing returns, decisions are made to reinforce the previous choices and progress is made in line with certain preferences. In the case of this equilibrium, defined as lock-in, although alternative options are known to provide more efficient results, it is not possible to turn to different options due to the sequence of events and the interaction between events. The organisation is forced to follow the current path, even if it knows that it produces lower-level results rather than the ones it wants to achieve (Crouch and Farrel, 2004; Sydow et al., 2009).

This study will use the terms of critical juncture and lock-in regarding a path-dependent model in the form of an interconnected definition. It describes a gradual critical juncture and a model of repetition of path dependence.

\section{Previous discussions of path dependence in urban studies}

When the planning literature is examined, it is observed that there are limited studies examining path dependence and critical junctures (Table 1). When the studies have been examined, it is observed that the term "critical juncture" has been used in order to emphasise the need for revealing and understanding "truly historic moments and critical junctures when there are efficacious choices available for planners and policy-makers" (Brooks, 1988; Johnson and Schaffer, 1985). Brooks wrote with a similar approach and identified four critical junctures in the history of urban planning in the United States (Brooks, 1988).

Sorensen (2011), in his study focusing on changes in property rights in Japan, touched on the theory of path dependence but adopted the gradual institutional change model proposed by Mahoney and Thelen (2010), 
Table 1 Literature research on the fields where studies have been conducted regarding path dependency and on the methods used

\begin{tabular}{|c|c|c|c|c|c|c|c|c|c|}
\hline \multirow{2}{*}{ Manuscript } & \multicolumn{7}{|c|}{ The Topic of the Article } & \multicolumn{2}{|c|}{ Method } \\
\hline & Planning & Politics & Technology & Sociology & Organization & Policy & Economy & Theoretical & Field survey \\
\hline Arthur (1989) & & & $*$ & & & & $*$ & $*$ & $*$ \\
\hline $\begin{array}{l}\text { Berisha and Cotella } \\
\text { (2015) }\end{array}$ & $*$ & & & & & & & $*$ & $*$ \\
\hline Booth (2011) & $*$ & & & $*$ & & & & $*$ & $*$ \\
\hline Bryson et al. (2017) & $*$ & & & & & $*$ & $*$ & $*$ & $*$ \\
\hline Bunker (2012) & $*$ & & & & & $*$ & & & \\
\hline Choi et al. (2019) & $*$ & & & & & & & $*$ & $*$ \\
\hline David (1994) & & & & & * & & & $*$ & $*$ \\
\hline David (2001) & & & & & & & $*$ & * & \\
\hline David (2007) & & & & $*$ & & & $*$ & $*$ & \\
\hline Dormois et al. (2005) & & & & $*$ & & $*$ & & * & $*$ \\
\hline Evenhuis (2017) & $*$ & & & & & & & $*$ & $*$ \\
\hline Follador et al. (2018) & $*$ & & & & & & & $*$ & $*$ \\
\hline Kaygisiz et al. (2005) & & & & & & $*$ & & $*$ & $*$ \\
\hline Lee (2012) & * & & & & & & $*$ & * & $*$ \\
\hline $\begin{array}{l}\text { Liebowitz and } \\
\text { Margolis (1995) }\end{array}$ & & & & & & & & * & $*$ \\
\hline Mahoney (2000) & & & & & & & & * & $*$ \\
\hline McFaul (1999) & & * & & & & & & * & $*$ \\
\hline McKeag (2019) & $*$ & & & & & & $*$ & * & $*$ \\
\hline Moulaert et al. (2007) & $*$ & & & & & & & * & $*$ \\
\hline Saint-Martin (2006) & & & & & & $*$ & & $*$ & \\
\hline Tasan-Kok (2015) & $*$ & & & & & $*$ & $*$ & $*$ & $*$ \\
\hline Theodore et al. (2012) & $*$ & & & & & & & $*$ & \\
\hline $\begin{array}{l}\text { Wilson and Dearden } \\
\text { (2011) }\end{array}$ & * & & & * & & & & * & \\
\hline
\end{tabular}

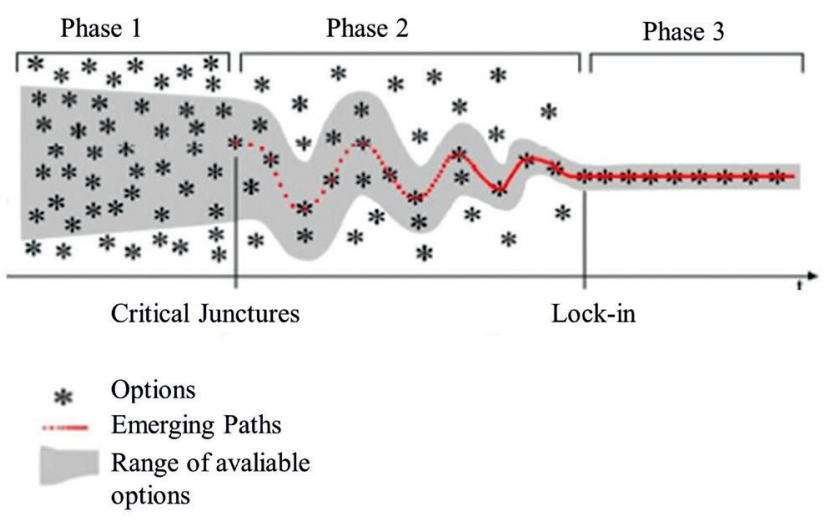

Fig. 1 The general model of path dependence (Sydow et al., 2009).

not the step-by-step model using critical juncture theory. Follador et al. (2018), in their article, they used the path analysis method. They focused on the question why similar results were reached despite that the institutional regulations and processes of the Curitiba Master Plan were very different in 2004 and 2014 . They touched on the factors affecting the resilience of the traditional practices in urban planning processes (Follador et al., 2018).

Dormois et al. (2005), using the approach of path dependency, in their study carried out in 2005 on French urban renewal projects, public and private actors and the regulatory framework, concluded that the existence of public policy-making procedures continued despite a policy discourse emphasising a new need for cooperation between the state, the market, and civil society, due to the unbalanced distribution of assets and resources. Booth (2011), conducted causal research reflecting some theoretical and methodological effects of approaches that accept the cultural integrity of planning. Bunker (2012) in his study where he claimed that the distinctive features of Australian metropolitan planning developed in the last century had been strengthened and expanded in metropolitan strategies of the $21^{\text {st }}$ century, explored ways by which 
more complex and more ambiguous challenges could be restructured through existing metropolitan strategic planning processes by using the method of path analysis.

In another study, path dependence in suburban development outcomes in Halifax, Nova Scotia was examined (Grant et al., 2019). Evenhuis (2017), compared the institutional change in governance regulations in the city regions of Saarland (Germany) and Teesside (England) from the 1970s to the current day in his study where he intended to make progress in the development of the path dependence approach focused on understanding institutional change at the national level in the context of economic development.

Moulaert et al. (2007) expressed path dependence in their studies comparing the discourses of neoliberal and social innovation on urban socio-economic change, aiming to develop the analytical framework of urban development by combining the spatialised "Regulation Theory with the elements of Cultural Political Economy and Urban Regime Theory". Theodore et al. (2012), state that pre-neoliberalist or non-neoliberalist institutions should not be regarded as institutional remains of the past, not belonging to our day; they have assessed through path dependency the routes these institutions would follow as the result of neoliberalist restructuring and their results, as institutions embraced neoliberalist restructuring methods.

Bryson et al. (2017), in a study he conducted in 2017, examined how ownership structure affects the transformation of a city and the role of the local authority in the financial management of land assets. McKeag (2019), examined the current trends affecting the decline of midsized cities in the United States and focusing on four cities in the state of Illinois, used path dependency approach in the process of creating a new paradigm in contemporary urban planning practice. Choi et al. (2019) studied greenbelt and New Town policy in the Seoul Metropolitan Area of Korea by developing a step-by-step critical juncture and repetition of the path dependency models based on historical institutionalisation. Berisha and Cotella (2015) examined the evolution of regional governance and spatial planning systems of the Balkan administration using path analysis. Lee (2012) sought to establish a conceptual framework of "government dependence" in South Korea, examining the multiplication of path dependency as an impact of innovation policy.

The studies are limited in Turkey compared to those in Western countries. Altuğ (2017) has tried to provide regional development efforts in Turkey with a new perspective by revealing the strengths and weaknesses of path dependency and lock-in approaches. Kayg1sız et al. (2005), in a study they carried out in 2005, analysed the factors affecting the development level of provinces using path analysis and clustering analysis. Öktem (2011) explained the spatial transformation of the city and focused on the international business district of the city in the BüyükdereMaslak axis. This aimed to show that the spatial transformation of the city is the outcome of a broader political project, globalisation, which has been constructed in the local areas through economic, political and cultural processes by deploying certain discourses. Tasan-Kok (2015) tested the concept of path dependency as a framework for analysing urban transformation in their study where they examined some deeply-embedded differences among urban development processes and examined the hybrid neo-liberal urban transformation along Levent-Maslak axis; an offshoot of the Central Business District of Istanbul.

\section{Findings: Site of the study - Kayseri (Turkey)}

The proclamation of the Republic is regarded as the starting year in the evolution of the settlement system, both in terms of the establishment of a modern nation-state and the permanent steps towards the construction of a national economy and delineation of the existing borders at a profound level (Tekeli, 2001). In the one-party regime, the Republican-led economic growth, based profoundly on the central government, led to the urbanisation of Turkey as a nation-state and Turkey's development-oriented, centralised and independent politico-economy pushed the demolish-construct approach into the open. With the passion of the modernisers of the Republic for "civilised life", urban areas became the main arenas for the modernisation project and the modernisation following the West. Foreign and Turkish experts were commissioned to create a "modern" and "civilised" society by popularising the secular image of the nation-state, starting with Ankara and then the cities of Anatolia; the city of Kayseri is no exception in this regard. In this context, urban areas became the stage of reproduction from 1930 to 1970 through expropriation and demolition and reconstruction (Gürler, 2003).

With the 1980s, Turkey followed export-oriented liberal growth policies. In the urban space where de-industrialisation is taking place, land prices increased rapidly with a tendency towards the construction sector and services in urban space. In this process, international bank and hotel chains, office buildings, shopping centres and consultancy firms prefer city centres. The process by which the hegemony of neoliberalism in Turkish cities began to dominate 
the city evolved from this period. During this process of the last forty years, demand-oriented distributive urban policies have been replaced by supply-oriented growth policies; policies that promote built environment production, urban growth and transformation, and practices that privatise public services, resources and spaces have been made dominant (Keskinok, 2006; Şengül, 2009). With the rise of neoliberalism, increasing the value of change in the production of urban space has been made a priority, and the way has been paved for creation of large undeserved income (Turan, 2009; Şengül, 2012).

In Turkey's adaptation to the neoliberal policies, Kayseri comes to the fore, and the city is made open for new investments by being demolished and constructed again. The destruction at the symbolic and ideological level resulting from these policies enables the destruction of the structure itself materially.

This study, aiming to make the responses of the construction-destruction processes at both spatial and ideological levels in the city of Kayseri comprehensible, intends to monitor the trajectory of external events identified by destructive and creative moments and tries to determine the moments of lock-in. This framework of analysis also sheds light on the diversity of policies that address similar urban development processes. Because familiar readings are insufficient regarding understanding this change encompassing country-specific initiatives in the urbanisation process in Turkey, this paper tries to describe the process through path analysis.

The analytical exercise presented in this paper will primarily examine the "organisational and institutional processes" that produce destructive and creative moments, and examine "conditional events" with historical milestones or junctures when describing the development process of the city to explain the lock-in processes. In addition, "trajectories of change", which are the product of destructive/creative moments and conditional events will be explained. Path dependency characterises historical sequences in which conditional events trigger deterministic institutional patterns, trajectories, or event chains (Mahoney, 2000). The deterministic pattern of development that is connected to the path will be defined by the combination of these readings.

\subsection{The first critical juncture: 1945 master plan applications - Modernisation and construction of CBD}

Kayseri has been one of the places where the striking transformations created by modernisation have been the most visible in daily life and the city. After the establishment of the Republic in 1923, the new regime needed a modern centre to represent itself in the cities and fulfilled this need by applying the destructive-constructive approach on a large scale. According to Eravşar (2000), in the pre-Republican period, the city had a medieval structure with organic-shaped dead-end streets surrounded by city walls and consisted of two parts as "inner city" and "outer city".

The first demolition decision for the city was structured with a focus on transportation. The government of the era started efforts to construct a grid road network in the city with linear axes built in the traditional fabric (Erkiletlioğlu, 2006). In 1933, through the planning scheme Burhanettin Çaylak prepared, such buildings symbolising the Republican regime were built in the square located at the juncture of transportation axes in the city centre.

In the 1940 s, zoning plans were similarly prepared for each city, without considering the traditional texture pattern throughout the country, and envisaged the grid system parcel layout. This planning approach, which would radically change the organic texture, was eagerly adopted by local governments. The city underwent significant changes with the Master Plan prepared by Gustav Oelsner Kemal Ahmet Aru in Kayseri in 1945 (Caliskan, 1995; Oelsner and Aru, 1945; Yilmaz Bakır, 2012). Although Arû (1998) initially proposed to protect the old city and to establish a new city on the side of Sivas street, the city council strongly opposed this development plan, which would result in a zoning plan that would lead to severe demolition (Fig. 2) (Arû, 1998). The main reason for the insistence on demolishing the old city instead of preserving it is the effort to consolidate the position of the dominant trade bourgeoisie in the socio-economic structure of the city by emphasising the commercial district nature of Kaleici where the central business district was located (Doğan, 2007b). As expressed by Tekeli (2009), it is "modernist planning that does not generally respect the urban fabric" (Fig. 1) (Tekeli, 2009). The implementations made in the period of Osman Kavuncu (1950-1957), which were accepted as a turning point in the history of the municipality in the city, became valid within the framework of an Oelsner - Aru Plan. They were an extension of a projected future of the city besides the needs specific to those years. When evaluated in terms of space production, central expansion and revitalisation, through reconstructing old neighbourhoods, they have become, objectively, the process where the dependence of the demolition-oriented developmental form is locked. The city remained mostly within its existing boundaries, demolished from the inner castle to Kicikapi and reorganised 


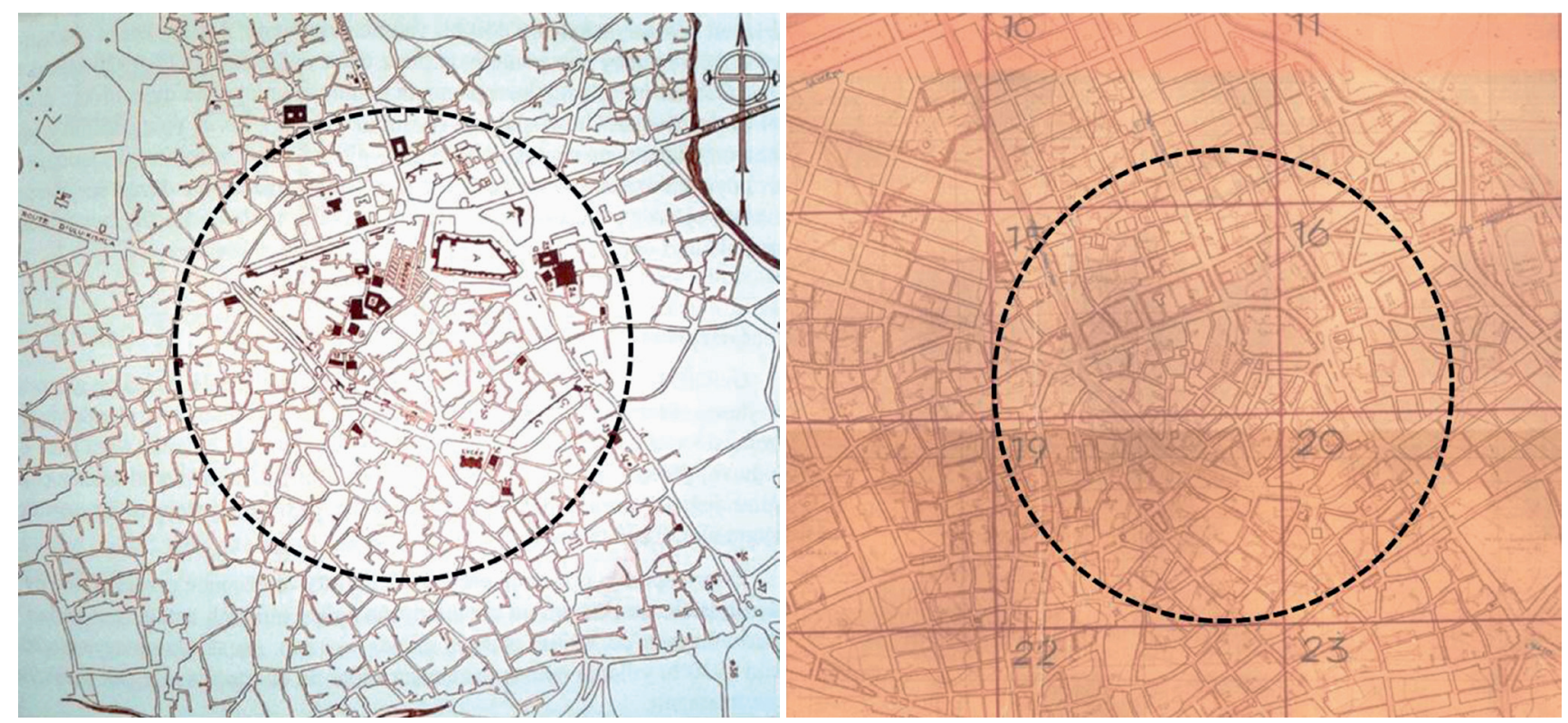

Fig. 2 Central Business District - Before and after the 1945 Oelsner - Aru Plan (Source: Kayseri Municipality Archive)

in the form of a grid plan; there is no single building example from the old city in this region, which is designated as CBD (Kocatürk, 2009).

During the CBD creation phase, the old narrow and dead-end neighbourhoods around the historic centre were destroyed; they have been replaced by a commercial area (central business district) consisting of new modern workplaces (banks, offices, office blocks) (Caliskan, 1995; Somuncu, 1998).

In the process of destruction, a traditional selective conservation approach was encouraged while acting with tabula rasa logic in traditional fabric. One hundred-year-old examples of civil architecture (houses and mansions around Kicikapi, specified as a place where the majority of Armenians and Greeks lived) were demolished with an eclectic protectionist approach. This meant that the social use of remaining historical, religious and political structures would mark the meaning of the city in terms of the political-ideological network, and in the words of Karatepe, were made to be visible like a trinket (Karatepe, 1999). These practices undoubtedly and significantly changed the daily lives of the citizens (the way they experience the city and their practices or identifying with it).

Kavuncu's management has a special place in the history of Turkey's municipality in terms of showing Schumpeter's creative destruction approach and how zoning plan practices can maximise the bringing of undeserved urban income to the public and how it can be made permanent (Tekeli et al., 1978).
In order to realise the expropriations necessary for this zoning activity, which creates the appearance of a large construction site in the city centre, a financing system was required. For this purpose, the local electricity company was used, Kavuncu increased the municipal share in the company to $75 \%$ with a loan and had himself elected as the chairman of the board of directors of the company; he convinced the same bank to issue "Electric Loans" for the company via some negotiations in the subsequent stages. The municipal administration then distributed these loans to landowners. With these practices, Kavuncu created undeserved income for the landowners that cannot be underestimated, saying "if there is no land, there is also no road", convincing the owners to leave half or $1 / 3$ of their land to the municipality.

\subsection{The second critical juncture: Expanding the CBD, "modernisation through tradition"}

In 1975, Yavuz Tasci, an architect, prepared a new master plan for the city of Kayseri. With this plan, the concept of a city with tall blocks and wide boulevards was started. The plan, proposing intensive development of the service sector, has developed a single-centred and linear form of growth scheme by strengthening the city centre. Protected area boundaries were determined for the traditional texture in the city centre, and a buffer development zone was proposed between that and the Cumhuriyet Neighbourhood where the trade and service sector were concentrated. During this period, housing use turned to commercial use 
due to its proximity to the city centre and new commercial districts were also built. Effectively, Yavuz Tasci revised the use of the Sahabiye Neighborhood, which had been defined as housing in the previous plan, as the Central Business District (CBD) (Yılmaz Bakır, 2012).

In addition to the dominance of the exchange value-centred approach, it can be seen that this approach was intended to be adopted by the wider public with the policies implemented in the first half of the 1980s. The structuring of the central built-up area in the form of demolition-construction continued after 1980. It resulted in the reduction of the urban site encompassing an area of about 145 hectares, comprising traditional residential architecture, put under protection in 1979 to 8.9 hectares in 1991 (Yilmaz, 2005).

In 1986, the new zoning plan defined the function of the CBD and development principles, such as linear development of the urban area around a single centre. The continuity of the demolition-oriented structure of the process was ensured (Kocaturk Özcan, 2006). It is more accurate to call the process of the 1990s, when traditional, cultural values and relationship networks the modernisation approach claimed would dissolve through economic-industrial development, reasserted themselves more strongly, the "revival" of the traditional and cultural rather than the return of them. Since the classical socio-economic development model brought about the update of "modernisation within the tradition", such a revival took place (Doğan, 2007a:p.112).

The policy of attracting as many people as possible to the automobile-based central business (trade) district of Kayseri, with its broad streets and boulevards, since the Kavuncu period continues to be vigorously encouraged. In this process, demolition activities in the name of replacing the old gained momentum during the Şükrü Karatepe period (1994-1998); while the social use of the buildings belonging to a certain period of history (Ottoman and Seljuk period) was sustained through the aesthetic presentation, demolitions that erased the influence and traces of the modernist period were carried out. The demolition of examples of civil architecture, dating back to the $19^{\text {th }}$ century, during the Kavuncu period focused on the structures created during the modern period of Şükrü Karatepe. The buildings constructed during the Republican period were destroyed and erased from the city's memory. What was demolished in this period were symbols of "Republican, elitist" ideology rather than the function of the buildings. The demolition of the old buildings was a condition for the formation of a new one, and the demolition-construction function was simultaneously carried out with the public space becoming a theatre scene. The buildings demolished within the scope of the project were the Central Post Office (Fig. 3), Feyzioglu House (Sait Azmi Office Blocks), Tekel Building, Alemdar Cinema Building, and Provincial Public Library (Tekinsoy, 2011). The Tan Cinema was demolished in the early 1960s as part of efforts to expand Cumhuriyet Square and enlarge the space in front of the Governor's Building.

\subsection{The third critical juncture: The formation of the new CBD - Global urbanisation}

In the urban development process, the collapse, which started with the incompatibility of the physical fabric and the functions of the central business district manifested itself differently in different parts of the centre. Residential areas turning away from the centre has made the CBD a target for uses in the search for new spaces and has attracted some central functions. In this process, density and accessibility-related problems and renewal pressures increased on CBD. In this process, the commercial services on Sivas Street and its surrounding damaged the functional-structural emphasis integrity with their urban prestige value and redirected high-level services to themselves. This tendency has prepared the physical and socio-economic collapse process in the CBD, especially since the 2000 s.
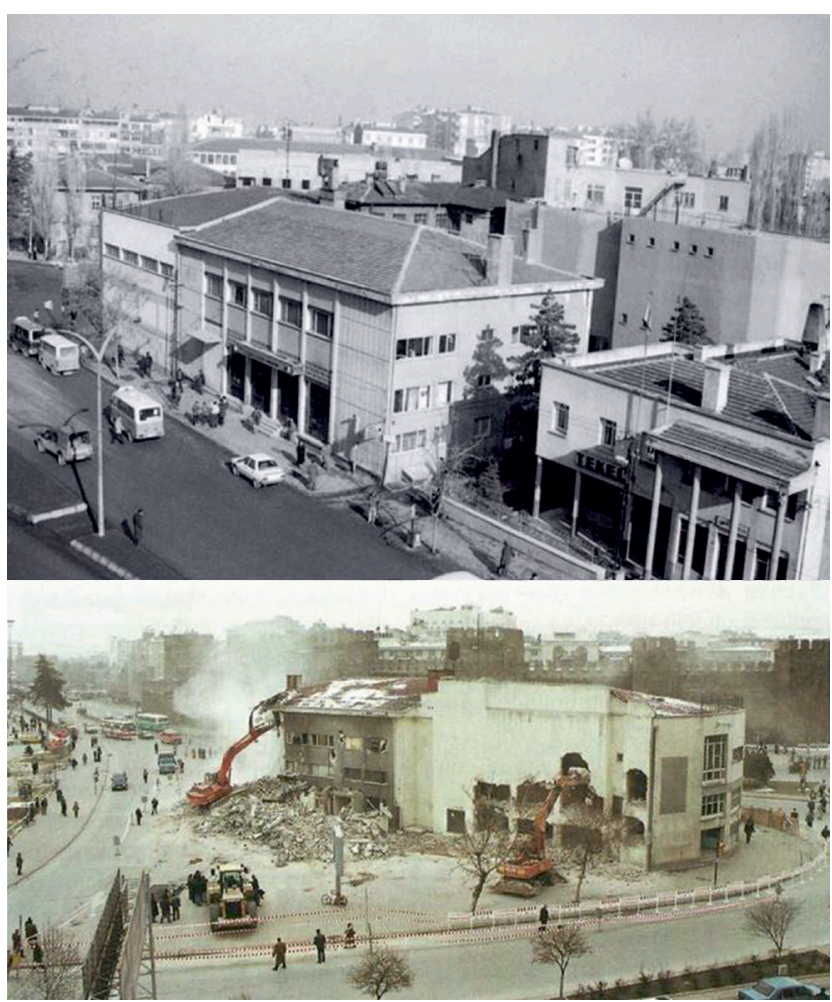

Fig. 3 Modernist buildings and demolition (Post Office and Tekel Buildings) (Tekinsoy, 2011) 
The public authority that had previously shaped the city and especially its centre, and the private capital, which was under the control of the public, are being replaced by a capital-oriented economic structure not controlled by the public and urban contradictions that it paves the way for. In this sense, Harvey (1973) has asserted that the processes determining the urban space are the real estate market within the second cycle of capital. According to him, the capitalist economy will use the urban space as a means of production to escape the crisis in the production sector reaching saturation. This notion of Harvey's can be put forward as an important contribution to the idea that the transition from the urbanisation of labour to the urbanisation of capital has transpired (Şengül, 2009; Şengül, 2012). The city of Kayseri also needs to be examined in the context of this change in urbanisation processes. The continuous and fragmentary urban spread-sprawl triggered the formation of housing areas with an imperfect relationship to the centre or with their own centres. Speculation for this purpose and the dissolution of the centre results in shopping mall type options and other negativities. Especially as the main determinant that has primed the dissolution in recent years are the shopping centres concentrated due to changing shopping patterns and consumption habits. This tendency to concentrate and spread has attracted the centre primarily on the Kayseripark, İpeksaray and then Forum, Sivas street axis (Y1lmaz Bakır, 2012).

The functions that want to make the most of the urban values by forming in the limited central space are located in the central business district by pushing the others out. Invasion-succession is one of the basic processes that determine the central structure in Kayseri. In the centre, where rent and land values are the highest in the city, the housing function is rapidly directed outwards, along with the traditional centre activities and services that are willing to accept lower rental rates.

A significant development in this process took place on 23 June 1998 when Mehmet Ozhaseki was elected as mayor. From this period (1998-2014) onwards, urban projects that would make "Kayseri a modern world city" (Kayseri Metropolitan Municipality, 2000) were put on the agenda. With the expansion of urban borders beginning from the 2000s, an intensive planning activity was conducted, and the growth of the city was envisioned with the plans realised on macro and micro scales.

In 2006, the institutional strategic plan of Kayseri Metropolitan Municipality was prepared, and the primary approach as the strategic objective was to plan new sub-commercial centres and industrial zones. In the Strategic Plan prepared in 2011, it was resolved that planning efforts must be continued to establish a multi-centred commercial structure; the "Kayseri Finance Centre Project" was initiated for this purpose.

The project, which was prepared to create a new mixeduse CBD in the area designated as the urban transformation project area within the existing central business district, was begun with a focus on demolition. The Sahabiye Neighbourhood, which is within the boundaries of the district, was declared to be an urban transformation area on 22 May 2015. All buildings were demolished and plans for designing a new financial centre were made (Fig. 4). The project area was planned as four separate areas, and the approximate area size is $515,196 \mathrm{~m}^{2}$. Within the scope of the project, demolition works have been completed for the first stage and construction works are ongoing.

Preliminary studies have also begun for the second stage, the boundaries of which have been determined. In the project, low-rise commercial units were planned in order to reveal the historical monuments in the south of the area during the street texture organisation; the intention was to revive the old street pattern of Kayseri by erecting buildings with the concept of Kayseri Houses.

The present historical and cultural texture will thus be unearthed, and the old street texture of Kayseri will be revived in this region by taking the map of Albert Gabriel

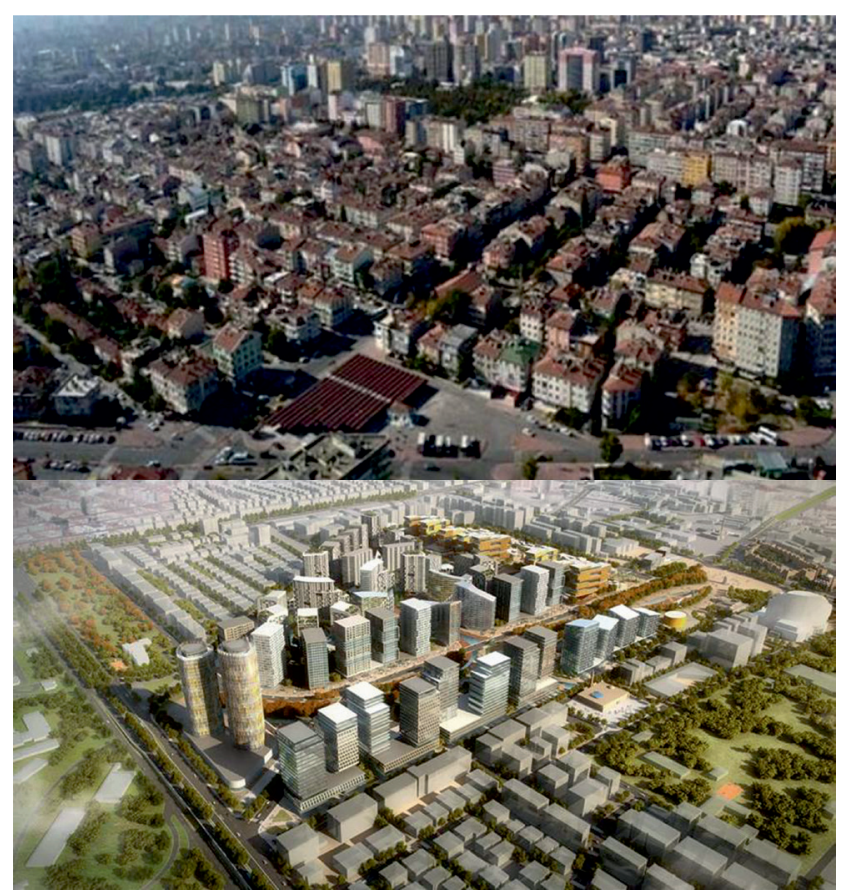

Fig. 4 Before and after the Sahabiye Financial Center project (Öztürk, 2019) 
as a reference. Following the proposed plan, buildings will be constructed with 3-4 storeys in the areas where Kayseri houses are located and with 12-15-18-20 storeys in the other parts (Anonymous, 2015; Anonymous, 2019).

\section{Conclusions and discussion}

A city's ability to respond to change is mainly based on its historical development. Urban space is a social environment in which new socio-spatial developments and factors of the accumulation process are mixed and shaped by what they carry from past socio-spatial development. This study was prepared to systematically analyse the transformation process of the central business district of Kayseri, with a focus on planning and demolition-construction, to form an evolutionary perspective. The study undoubtedly requires a comprehensive analysis of large-scale urban development with a large number of components, so path dependency has been used as a more sophisticated way to draw links between historical events and development trajectories, with critical junctures included as the most important processes (Table 2).
The CBD of Kayseri was destroyed by the tabula rasa approach to the old city centre with the establishment of the Republic and was then shaped by the new Republic and its economic structure. This situation is examined in the study via the relation between undeserved urban income and the political mobilisation process during the Republic's history. It has been described as a process that started with the discourse of creative destruction and resulted mainly in mass demolition for the sake of modernisation. This demolition-driven renewal phenomenon has created a path-dependent trend, after which the management's policy choices have been locked into a demolish-build model.

The metropolitan development process that began in the 1970s brought with it a new demolish-build process. Since Kayseri city centre cannot meet the needs of the growing service sector, modern office buildings along the Sivas street axis have started to form a new centre. Since the classical socio-economic development model adopted by the local government in this period brought about the update of "modernisation within the tradition",

Table 2 Contingent Events and Critical Junctures of Kayseri CBD Formation

\begin{tabular}{|c|c|c|c|}
\hline Contingent events & Planner/Periods & Intervention & Importance for $\mathrm{CBD}$ \\
\hline $\begin{array}{l}\text { - The proclamation of the Republic of Turkey } \\
\text { (1923) }\end{array}$ & $\begin{array}{l}\text { Plan scheme prepared by } \\
\text { Burhanettin Caylak (1933) }\end{array}$ & $\begin{array}{l}\text { Demolition urban } \\
\text { texture (Tabula Rasa) }\end{array}$ & The first critical juncture \\
\hline $\begin{array}{l}\text { The first demolition decision for the city was } \\
\text { structured with a focus on transportation } \\
(1933-1945)\end{array}$ & & & $\begin{array}{l}\text { Modernisation and } \\
\text { construction of } C B D\end{array}$ \\
\hline $\begin{array}{l}\text { - Election of the entrepreneurial mayor Osman } \\
\text { Kavuncu (1950-1957) }\end{array}$ & $\begin{array}{c}\text { Gustav Oelsner - Kemal Ahmet } \\
\text { Aru Plan (1945) }\end{array}$ & & \\
\hline $\begin{array}{l}\text { Development of single-centred and linear form } \\
\text { of urban growth scheme }\end{array}$ & Yavuz Tascı Master plan (1975) & $\begin{array}{l}\text { The buildings } \\
\text { constructed during the } \\
\text { Republican period } \\
\text { were destroyed } \\
\text { in the CBD }\end{array}$ & The second critical juncture \\
\hline $\begin{array}{l}\text { - Election of the new mayor Şükrü Karatepe } \\
\text { (1994) }\end{array}$ & & & Expanding the $C B D$, \\
\hline \multirow[t]{2}{*}{ • "Modernisation within the tradition", } & & CBD expansion & $\begin{array}{l}\text { "Modernisation through } \\
\text { tradition" }\end{array}$ \\
\hline & $\begin{array}{l}\text { Melahat Toplaoğlu- Bülent } \\
\text { Berksan Master Plan (1986) }\end{array}$ & & \\
\hline $\begin{array}{l}\text { - Election of the mayor Mehmet Ozhaseki } \\
(1998-2015)\end{array}$ & $\begin{array}{l}\text { Nadir Doğan Master Plan } \\
\qquad(2006)\end{array}$ & New CBD construction & The third critical juncture \\
\hline - Entrepreneurial Urban Governance & & & $\begin{array}{l}\text { The formation of the new } C B D- \\
\text { Global Urbanization }\end{array}$ \\
\hline $\begin{array}{l}\text { - Kayseri Metropolitan Municipality Strategic } \\
\text { plan (2006) }\end{array}$ & & & \\
\hline - New Strategic Plan prepared in 2011 & & & \\
\hline - Multi-centred commercial structure & & & \\
\hline $\begin{array}{l}\text { - } \text { "Kayseri Finance Centre Project" was initiated } \\
(2015)\end{array}$ & & & \\
\hline $\begin{array}{l}\text { - Demolition of Sahabiye Neighbourhood and } \\
\text { starting New CBD project (2016) }\end{array}$ & & & \\
\hline
\end{tabular}


the revitalisation process started in the city. During this period, it was re-demolished and reconstructed in parts to form local elements.

Another factor affecting the region is the global service sector that began in the 1980s. With the 2000s, the most important of the projects realised in this direction in the city, which envisages its future self through the vision of the world city adopted by the local government, is the new financial centre. This was, once again, developed with the logic of tabula rasa and built as a result of a major demolition process. While the traditional CBD is profoundly an area where domestic firms have settled, the newly created Sahabiye Finance Centre has been designed to be preferred by global service firms and large domestic firms. Due to the phenomenon of competition, which has recently become the main discourse, Kayseri has to be a modern international business district in order to become a world city. However, global is the metaphor used by politicians to set up their urban mega-projects, and by investors

\section{References}

Altuğ, F. (2017) "Evrimsel ekonomik coğrafya perspektifinden bölgesel ekonomik gelişme: Yol bağımlılığı ve kilitlenme yaklaşımı" (Regional Economic Development in The Evolutional Economic Geography Perspective: Path Dependency and Lock-in Approach), Marmara Coğrafya Dergisi, 36, pp. 97-110. (in Turkish)

Anonymous (2015) "Sahabiye Kentsel Dönüsüm (Kurumsal eğitim dökümanları)" (Sahabiye Institutional documents), Kayseri Metropolitan Municipality Department of Urban Transformation, Kayseri. [online] Available at: http://www.sahabiyedonusum.com/ [Accessed: 17 Nowember 2015] (in Turkish)

Anonymous (2019) "Sahabiye Kentsel Dönüşüm" (Sahabiye Urban Renewal), Erkut Group, [online] Available at: https://www.erkut. com.tr/projeler/taahhutprojelerimiz/SahabiyeKentselDonusum [Accessed: 12 October 2019] (in Turkish)

Arthur, W. B. (1989) "Competing Technologies, Increasing Returns, and Lock-in By Historical Events", The Economic Journal, 99(394), pp. 116-131. https://doi.org/10.2307/2234208

Arû, K. A. (1998) "Türk kenti: Türk kent dokularının incelenmesine ve bugünkü koşullar içinde değerlendirilmesine ilişkin yöntem araştırması" (Turkish city: a method research on the analysis of Turkish urban textures and their evaluation in today's conditions), Harbiye, Yapı-Endüstri Merkezi Yayınları, İstanbul, Turkey. (in Turkish)

Berisha, E., Cotella, G. (2015) "Spatial Planning in the Balkans between Transition, European Integration and Path-dependency", In: Proceedings of the 5th International Conference on European Studies 5th ICES 6-7 November 2015, Tirana, Albania, pp. 41-71. [online] Available at: http://dspace.epoka.edu.al/handle/1/1313 [Accessed: 20 October 2019]

Berman, M. (1982) "All That Is Solid Melts Into Air", Simon and Schuster, New York, NY, USA. to ease the development of luxurious administration centres and land/property speculation. Kayseri should meet the global discourse but take measures to reduce the pressures it will create in the city.

The perspective of path-dependence emphasises the tendency of policy choices and large investments for leading cities to irreversible development paths. It also allows for increased attention to the timing of policy interventions and facilitates understanding of the dependence on demolitionist-constructionist attitude in the continuous renewal of the central business district.

This study shows that analysing path dependence is a useful way of understanding complex urban transformations. By delineating unexpected situations, various institutional and organisational processes and creative and destructive moments within the framework of analysis, this article shows that path dependence can be a useful advantage point in the comparison of planning and regional management systems.

Booth, P. (2011) "Culture, planning and path dependence: some reflections on the problems of comparison", Town Planning Review, 82(1), pp. 13-28.

https://doi.org/10.3828/tpr.2011.4

Brenner, N. (2000) "Building 'Euro-Regions': Locational Politics and the Political Geography of Neoliberalism in Post-Unification Germany", European Urban and Regional Studies, 7(4), pp. 319-345. https://doi.org/10.1177/096977640000700403

Brenner, N., Theodore, N. (2002) "Cities and the geographies of "actually existing neoliberalism"", Antipode, 34(3), pp. 349-379. https://doi.org/10.1111/1467-8330.00246

Brenner, N., Theodore, N. (2005) "Neoliberalism and the urban condition", City, 9(1), pp. 101-107. https://doi.org/10.1080/13604810500092106

Brooks, M. P. (1988) "Four Critical Junctures in the History of the Urban Planning Profession: An Exercise in Hindsight", Journal of the American Planning Association, 54(2), pp. 241-248. https://doi.org/10.1080/01944368808976481

Bryson, J. R., Daniels, P. W. (eds.) (2007) "The Handbook of Service Industries", Edward Elgar Publishing, Cheltenham, UK.

Bryson, J. R., Daniels, P. W., Warf, B. (2004) "Service worlds: People, technology, organizations", Routledge, London, UK.

Bryson, J. R., Mulhall, R. A., Song, M., Kenny, R. (2017) "Urban assets and the financialisation fix: land tenure, renewal and path dependency in the city of Birmingham", Cambridge Journal of Regions, Economy and Society, 10(3), pp. 455-469. https://doi.org/10.1093/cjres/rsx013

Bunker, R. (2012) "Reviewing the Path Dependency in Australian Metropolitan Planning", Urban Policy and Research, 30(4), pp. $443-452$.

https://doi.org/10.1080/08111146.2012.700638 
Carter, R. A. (1982) "The effect of proposed district centers on Melbourne's central business district", Urban Policy and Research, 1(1), pp. 2-7. https://doi.org/10.1080/08111148208522667

Cezar, M. (1983) "Typical Commercial Buildings of the Ottoman classical Period and the Ottoman Construction System", Genel yayın: Türkiye İş Bankası Cultural Publications, Ankara, Turkey.

Chapin, F. S., Hightower, H. C. (1965) "Household activity patterns and land use", Journal of the American Institute of Planners, 31(3), pp. $222-231$ https://doi.org/10.1080/01944366508978169

Choi, C. G., Lee, S., Kim, H., Seong, E. Y. (2019) "Critical junctures and path dependence in urban planning and housing policy: A review of greenbelts and New Towns in Korea's Seoul metropolitan area", Land Use Policy, 80, pp. 195-204. https://doi.org/10.1016/j.landusepol.2018.09.027

Corbusier, L. (2014) "Şehircilik" (Urbanism), Daimon, Istanbul, Turkey. (in Turkish)

Crouch, C., Farrel, H. (2004) "Breaking the Path of Institutional Development? Alternatives to the New Determinism", Rationality and Society, 16(1), pp. 5-43. https://oi.org/10.1177/1043463104039874

Cunningham, S. (2010) "Joseph A. Schumpeter, Capitalism, socialism, and democracy", International Journal of Cultural Policy, 16(1), pp. 20-22. https://doi.org/10.1080/10286630902807278

Çalışkan, N. (1995) "Kuruluşundan günümüze Kayseri Belediyesi" (Kayseri Municipality since its establishment), Kayseri Büyükşehir Belediyesi Kültür Yayınları, Kayseri, Turkey. (in Turkish)

David, P. A. (1985) "Clio and the Economics of QWERTY", The American Economic Review, 75(2), pp. 332-337.

David, P. A. (1994) "Why are institutions the 'carriers of history'? Path dependence and the evolution of conventions, organizations and institutions", Structural Change and Economic Dynamics, 5(2), pp. $205-220$. https://doi.org/10.1016/0954-349X(94)90002-7

David, P. A. (2001) "Path Dependence, its Critics and the Quest for 'Historical Economics'", In: Garrouste, P., Ioannides, S. (eds.) Evolution and Path Dependence in Economic Ideas: Past and Present, Edward Elgar Publishing, Cheltenham, UK, pp. 15-40.

David, P. A. (2007) "Path Dependence: a foundational concept for historical social science", Cliometrica, 1(2), pp. 91-114. https://doi.org/10.1007/s11698-006-0005-x

Doğan, A. E. (2007a) "Mekan üretimi ve gündelik hayatın birikim ve emek süreçleriyle ilişkisine Kayseri'den bakmak" (The Relationship between space production and daily life's accumulation and labor processes), Praksis, 16, pp. 91-122. (in Turkish)

Doğan, A. E. (2007b) "Eğreti kamusallık: Kayseri Örneğinde Islamc1 Belediyecilik" (Makeshift publicity: Islamic municipalism in the case of Kayseri), İletişim Yayınları, Istanbul, Turkey. (in Turkish)

Dormois, R., Pinson, G., Reignier, H. (2005) "Path-dependency in public-private partnership in French urban renewal", Journal of Housing and the Built Environment, 20(3), pp. 243-256. https://doi.org/10.1007/s10901-005-9008-3

Eravşar, O. (2000) "Seyahatnamelerde Kayseri" (Kayseri in Travelogues), Kayseri Ticaret Odası, Kayseri, Turkey. (in Turkish)
Erkiletlioğlu, H. (2006) "Geniş Kayseri Tarihi" (Wide Kayseri History) Can Matbaas1, Kayseri, Turkey. (in Turkish)

Evenhuis, E. (2017) "Institutional change in cities and regions: a path dependency approach", Cambridge Journal of Regions, Economy and Society, 10(3), pp. 509-526. https://doi.org/10.1093/cjres/rsx014

Follador, D., Duarte, F., Carrier, M. (2018) "Institutional Arrangements and Political Shifts in Curitiba, Brazil: A Comparative Analysis of the 2004 and 2014 Master Plans", Journal of Planning History. https://doi.org/10.1177/1538513218762327

Giddens, A., Pierson, C. (1998) "Conversations with Anthony Giddens: Making Sense of Modernity", Stanford University Press, Palo Alto, CA, USA.

Gottman, J. (1976) "Development of Urban Centrality", Istanbul University Pub, Geography Institute Pub, Istanbul, Turkey.

Grant, J. L., Filion, P., Low, S. (2019) "Path dependencies affecting suburban density, mix, and diversity in Halifax", The Canadian Geographer/Le Géographe canadien, 63(2), pp. 240-253. https://doi.org/10.1111/cag.12496

Gürler, E. (2003) "Kentsel Yeniden Üretim Süreci Üzerine Karşılaştırmalı Çalışma: İstanbul Örneği" (Comparative Study on Urban Reproduction Process: The Case of Istanbul), In: Kentsel Dönüşüm Sempozyumu Bildiriler Kitabı, Yıldız Teknik Üniversitesi BasımYayın Merkezi, İstanbul, Turkey, pp. 113-158. (in Turkish)

Harvey, D. (1973) "Social justice and the city", The University of Georgia Press, Athens, Greece.

Harvey, D. (1999) "Time-space compression and the postmodern condition", In: The condition of postmodernity: an enquiry into the origins of cultural change, Blackwell, Oxford, UK, pp. 98-118.

Harvey, D. (2000) "Spaces of hope", Edinburgh University Press, Edinburgh, UK.

Harvey, D. (2006) "Neoliberalism as creative destruction", Geografiska Annaler: Series B, Human Geography, 88(2), pp. 145-158. https://doi.org/10.1111/j.0435-3684.2006.00211.x

Haughton, G., Hunter, C. (2004) "Sustainable cities", Routledge, London, UK.

He, S., Wu, F. (2009) "China's Emerging Neoliberal Urbanism: Perspectives from Urban Redevelopment", Antipode, 41(2), pp. $282-304$ https://doi.org/10.1111/j.1467-8330.2009.00673.x

Hollenstein, L., Purves, R. (2010) "Exploring place through user-generated content: Using Flickr tags to describe city cores", Journal of Spatial Information Science (JOSIS), 1, pp. 21-48. https://doi.org/10.5311/JOSIS.2010.1.3

Jessop, B. (2018) "Neoliberalism and Workfare: Schumpeterian or Ricardian?", In: Cahill, D., Cooper, M., Konings, M., Primrose, D. (eds.) SAGE handbook of neoliberalism, pp. 347-358. https://doi.org/10.4135/9781526416001.n28

Johnson, D. A., Schaffer, D. (1985) "Learning from the Past - The History of Planning: Introduction", Journal of the American Planning Association, 51(2), pp. 131-133. https://doi.org/10.1080/01944368508976204

Karatepe, Ş. (1999) "Kendini kuran şehir" (The city that established itself), Kayseri Büyükşehir Belediyesi, Kayseri, Turkey. (in Turkish) 
Kayseri Metropolitan Municipality (2000) "Kayseri Metropolitan City Strategic Plan Report, 1999-2004", Kayseri Metropoliten Municipality Rep.II, Kayseri, Turkey. [online] Available at: http://www.sp.gov.tr/tr/stratejik-plan [Accessed: 11 November 2010] (in Turkish)

Kaygısız, Z., Saraçlı, S., Dokuzlar, K. U. (2005) "İllerin gelişmişlik düzeyini etkileyen faktörlerin path analizi ve kümeleme analizi ile incelenmesi" (Examination of the factors affecting the development level of provinces by path analysis and clustering analysis), In: VII. Ulusal Ekonometri ve İstatistik Sempozyumu, Istanbul, Turkey, pp. 26-27. (in Turkish)

Keskinok, H. Ç. (2006) "Kentleşme Siyasaları" (Urbanization Policies), Kaynak Yayınları, Istanbul, Turkey. (in Turkish)

Keskinok, H. Ç. (2010) "Urban Planning Experience of Turkey in the 1930s", METU Journal of the Faculty of Architecture, 27(2), pp. 173-188.

https://doi.org/10.4305/METU.JFA.2010.2.9

Kocatürk, F. (2009) "Kayseri'nin Kentsel Değişim Süreci" (Kayseri's Urban Change Process), TOL, Kayseri, 7, pp. 52-57. (in Turkish)

Kocatürk Özçan, F., (2006) "Konut alanı yerseçimi ve hane halkı hareketliliğine yönelik kuramsal birinceleme" (A theoretical examination of residential area selection and household mobility), Erciyes Üniversitesi Sosyal Bilimler Enstitüsü Dergisi, 21, pp. 73-95. (in Turkish)

Lee, T. K. (2012) "Rethinking Path Dependency and Regional InnovationPolicy Induced 'Government Dependency': The Case of Daedeok, South Korea", World Technopolis Review, 1(2), pp. 92-106. https://oi.org/10.7165/wtr2012.1.2.92

Lefebvre, H. (2000) "Everyday life in the modern world", The Athlone Press, London, UK.

Lefebvre, H., Bononno, R., Smith, N. (2003) "The urban revolution", University of Minnesota Press, Minneapolis, MN, USA.

Liebowitz, S. J., Margolis, S. E. (1995) "Path Dependence, Lock-In, and History", Journal of Law, Economics \& Organization, 11(1), pp. 205-226.

Lipietz, A. (1994) "Post-Fordism and democracy" In: Post-Fordism: a reader, Blackwell, Oxford, UK, pp. 338-358.

Lovering, J., Türkmen, H. (2011) "Bulldozer Neo-liberalism in Istanbul: The State-led Construction of Property Markets, and the Displacement of the Urban Poor", International Planning Studies, 16(1), pp. 73-96.

https://doi.org/10.1080/13563475.2011.552477

Mahoney, J. (2000) "Path Dependence in Historical Sociology", Theory and Society, 29(4), pp. 507-548.

Mahoney, J., Thelen, K. (2010) "A theory of gradual institutional change", Explaining Institutional Change: Ambiguity, agency, and power, 1, pp. 1-37.

https://doi.org/10.1017/CBO9780511806414.003

McFaul, M. (1999) "Institutional Design, Uncertainty, and Path Dependency during Transition: Cases from Russia", Constitutional Political Economy, 10(1), pp. 27-52. https://doi.org/10.1023/A:1009046431139

McKeag, A. (2019) "Planning for Slow Growth and Decline in Mid-Sized US Cities", Master Thesis, KTH Royal Institute of Technology in Stockholm.
Morrison, C., Croucher, R. (2010) "Moldovan employment relations: "path dependency"?", Employee Relations, 32(3), pp. 227-247. https://doi.org/10.1108/01425451011038771

Moulaert, F., Martinelli, F., González, S., Swyngedouw, E. (2007) "Introduction: Social Innovation and Governance in European Cities: Urban Development Between Path Dependency and Radical Innovation", European Urban and Regional Studies, 14(3), pp. 195-209. https://doi.org/10.1177/0969776407077737

Murphy, R. E., Vance, J. E., Epstein, B. J. (1955) "Internal Structure of the CBD", Economic Geography, 31(1), pp. 21-46. https://doi.org/10.2307/142409

Murphy, R. E. (2017) "The Central Business District: A Study in Urban Geography", Taylor and Francis, London, UK.

Oelsner, G., Aru, K. A. (1945) "Kayseri Master Plan", Kayseri Municipality Collection, Kayseri, Turkey.

Ozus, E., Turk, S. S., Dokmeci, V. (2011) "Urban Restructuring of Istanbul", European Planning Studies, 19(2), pp. 331-356. https://doi.org/10.1080/09654313.2010.515826

Öktem, B. (2011) "The Role of Global City Discourses in the Development and Transformation of the Büyükdere-Maslak Axis into the International Business District of Istanbul", International Planning Studies, 16(1), pp. 27-42. https://doi.org/10.1080/13563475.2011.552498

Öztürk, M. (2019) "Kentsel dönüşümde coğrafi bilgisistemleri destekli alan araştırması ve Sahabiye Mahallesi üzerinde uygulama", (Geographical information systems assisted field research in urban transformation and application on Sahabiye Neighborhood), Erciyes Üniversitesi Fen Bilimleri Enstitüsü, Yayınlanmamış Yüksek Lisans Tezi, Kayseri, Turkey. (in Turkish)

Park, R., Burgess, E. (1925) "The City: Suggestions for the Investigation of Human Behavior in the Urban Environment", The University of Chicago Press, Chicago, IL, USA.

Pierson, P. (2000) "Increasing Returns, Path Dependence, and the Study of Politics", American Political Science Review, 94(2), pp. 251-267. https://doi.org/10.2307/2586011

Saint-Martin, D. (2006) "Path Dependence and Self-Reinforcing Processes in the Regulation of Ethics in Politics: Toward a Framework for Comparative Analysis", In: Saint-Martin, D., Thompson, F. (eds.) Public Ethics and Governance: Standards and Practices in Comparative Perspective (Research in Public Policy Analysis and Management), Emerald Group Publishing Limited, Bingley, UK, pp. 5-27. https://doi.org/10.1016/S0732-1317(05)14002-0

Sassen, S. (2000) "Cities in the World Economy", Pine Forge Press, Thousand Oaks, CA, USA.

Sassen, S. (1991) "The Global City: New York, London, Tokyo", Princeton University Press, Princeton, NJ, USA.

Somuncu, M. (1998) "Cumhuriyetin 75.Y1lında Kayseri" (75th Anniversary of the Republic and Kayseri), Kayseri Valiliği Yayını, Ankara, Turkey, pp. 116-117. (in Turkish)

Sorensen, A. (2011) "Evolving Property Rights in Japan: Patterns and Logics of Change", Urban Studies, 48(3), pp. 471-491. https://doi.org/10.1177/0042098010390241 
Stein, R. (2003) "Economic Specialization in Metropolitan Areas Revisited: Transactional Occupations in Hamburg, Germany", Urban Studies, 40(11), pp. 2187-2205. https://doi.org/10.1080/0042098032000123240

Sydow, J., Schreyögg, G. Koch, J. (2009) "Organizational Path Dependence: Opening the Black Box", Academy of Management Review, 34(4), pp. 689-709.

https://doi.org/10.5465/amr.34.4.zok689

Şengül, H. T. (2009) "Kentsel Çelişki ve Siyaset: Kapitalist kentleşme süreçlerinin eleştirisi" (Urban Contradiction and Politics: Criticism of capitalist urbanization processes), İmge Kitabevi Yayınları, Ankara, Turkey. (in Turkish)

Şengül, H. T. (2012) "İktidar. Siyaset Bilimi: Kavramlar, İdeolojiler, Disiplinler Arası İlişkiler" (Power. Political Science: Concepts, Ideologies, Interdisciplinary Relations), Yordam Kitap, pp. 41-53. (in Turkish)

Tasan-Kok, T. (2015) "Analysing Path Dependence to Understand Divergence: Investigating Hybrid Neo-liberal Urban Transformation Processes in Turkey", European Planning Studies, 23(11), pp. 2184-2209.

https://doi.org/10.1080/09654313.2015.1018458

Tasan-Kok, T., Baeten, G. (eds.) (2011) "Contradictions of neoliberal planning: Cities, Policies, and Politics", Springer Netherlands, Dordrecht, Netherlands.

https://doi.org/10.1007/978-90-481-8924-3

Tekeli, İ. (2001) "Modernite aş1lırken kent planlaması", (Urban planning while transcending modernity), Ankara İmge Kitabevi, Ankara, Turkey. (in Turkish)

Tekeli, İ. (2009) "Cumhuriyetin belediyecilik öyküsü, 1923-1990" (The history of the municipality of the Republic, 1923-1990), Tarih Vakfı Yurt Yayınları, Istanbul, Turkey. (in Turkish)

Tekeli, İ., Ortaylı, İ., Türkcan, E. (1978) "Türkiye'de belediyeciliğin evrimi" (The evolution of municipality in Turkey), Türk İdareciler Derneği, Ankara, Turkey. (in Turkish)

Tekinsoy, K. (2011) "Kayseri’nin imarı ve mekânsal gelişimi" (Urbanism and spatial development of Kayseri), Kayseri Büyükşehir Belediyesi, Kayseri, Turkey. (in Turkish)
Theodore, N., Peck, J., Brenner, N. (2012) "Neoliberal Urbanism: Cities and the Rule of Markets", İdealkent, 7(3), pp. 21-37.

Thorns, D. C. (2002) "The Transformation of Cities: Urban Theory and Urban Life", Palgrave Macmillan, Gordonsville, VA, USA. https://doi.org/10.1007/978-1-4039-9031-0

Thurstain-Goodwin, M., Unwin, D. (2000) "Defining and Delineating the Central Areas of Towns for Statistical Monitoring Using Continuous Surface Representations", Transactions in GIS, 4(4), pp. 305-317. https://doi.org/10.1111/1467-9671.00058

Tournikiotis, P. (1999) "The Historiography of Modern Architecture", London: MIT Press, Cambridge, MA, USA.

Turan, M. (2009) "Türkiye'de Kentsel Rant: Devlet Mülkiyetinden Özel Mülkiyete" (The urban rent in Turkey from state ownership to private ownership), Tan Kitabevi, Kızılay, Ankara, Turkey. (in Turkish)

Urry, J. (2000) "Sociology beyond societies: Mobilities for the twenty-first century", Routledge, London, UK.

Wilson, A., Dearden, J. (2011) "Phase transitions and path dependence in urban evolution", Journal of Geographical Systems, 13(1), pp. 1-16. https://doi.org/10.1007/s10109-010-0134-4

Yaguang, S. (2011) "Development and Characteristics of Central Business District Under the Philosophy of Health", Procedia Engineering, 21, pp. 258-266. https://doi.org/10.1016/j.proeng.2011.11.2013

Yılmaz, N. (2005) "Kent Merkezlerindeki Kentsel Sit Alanlarında Değişim Sürecinin Değerlendirilmesi Kayseri Kentsel Sit Alanı Ve Talas Kentsel Sit Alanları Örneği" (Evaluation of Change Process in Urban Sites in City Centers Kayseri Urban Sites and Talas Urban Sites), Master dissertation, İstanbul Technical University, Institute of Sciences. (in Turkish)

Yılmaz Bakır, N. (2012) "Kentsel planlama ve proje bütünleşme süreci Kayseri kenti örneği" (Urban planning and project integration process), PhD Thesis, Mimar Sinan Fine Art University, Institute of Sciences. (in Turkish) 